\title{
A REVIEW ON TRADITIONAL VETERINARY MEDICAL PRACTICES IN SRI LANKA WITH SPECIAL REFERENCE TO CATTLE DISEASES
}

\author{
ERHSS Ediriweera $^{1}$, NGAAS Nanayakkara ${ }^{2}$, OTMRKSB Kalawana ${ }^{2}$, YKSSL Sugathadasa ${ }^{3}$ \\ ${ }^{1}$ Department of Nidana Chikithsa, Institute of Indigenous Medicine, University of Colombo, Rajagiriya, Sri \\ Lanka, ${ }^{2}$ Intern Medical Officer, ${ }^{3}$ Ayurvedic Physician
}

Accepted: $21^{\text {st }}$ July 2010

\begin{abstract}
Sri Lanka has well developed systems of traditional veterinary medicine. Unfortunately most of our people today, are unaware of these practices and they generally seek western modern veterinary medicinal assistance due to this unawareness and also for convenience in their busy lives. Hence, this study was undertaken to collect and preserve the old knowledge and practices. Data were gathered from traditional veterinary physicians in Central and Sabaragamuwa provinces, Olla leaves and text books. These physicians have a knowledge in identifying and treating diseases, preparation of medicines, mode of drug administration, burning of vital points (moxibustion), branding, and blood letting. Specific applications of metaphysical nature such as mystical diagrams and charms, 'Yanthra' or 'Kem' are also used. The striking feature of this treatment regimen is the incorporation of both physical (visible) and metaphysical (invisible) methods to treat diseases as preventive and therapeutic measures. The medicinal preparations consist of herbs, metals, minerals and animal products including milk products, eggs, bones, meat, spider web, anthill mud and human urine. It is also observed that the traditional veterinary medicinal practices; especially in treatment of cattle, are very diverse.
\end{abstract}

Key words: Cattle diseases, Traditional veterinary remedies, Sri Lanka

\section{INTRODUCTION}

Sri Lanka has a well developed traditional system of Medicine, Agricultural methods, Architecture \& Culture since ancient days. Traditional physicians of Sri Lanka regularly treated human patients, animals; especially cattle, other household animals, elephants \& horses for various ailments. These treatment methods were passed down from generation to generation through writings on olla leaves or being taught by father-to-son. According to the "Mahawansa", a historical chronicle of Sri Lanka, veterinary hospitals were established by the ancient kings with veterinary doctors appointed to treat animals; especially cattle, in most villages. The reason for paying special attention to cattle was due to a close relationship between man and the domesticated cattle since early days of human history. Its milk, meat, skin, horns, cow dung, urine, etc have been used as food or medicine. These animals were further used in agriculture and transportation.

According to the Sri Lankan traditional veterinary physicians, there are 4,448 varieties of Weppu (Lethargy) Adappan (Nasal discharge and tremors) diseases, 120 of general diseases, 300 diseases of hepato billariary system, 8 diseases along the spine, 300 diseases of the intestines, 13 diseases of the joints of the legs, 1,448 diseases of the head and four extremities that may occur in cattle. Although this classification of diseases is huge in number, the Sri Lankan traditional veterinary physicians have *Corresponding author: ayurvedadocsujatha@yahoo.com the knowledge to identify and treat them by using various methods. Some of these methods are described below.

The commonest route for drug administration in cattle is through the mouth. Other routes of drug administration include nose, ear, and anus. The 'Marma' or vital points of the body; akin to acupuncture pressure points, are popular application sites for therapy where branding of special patterns in order to stimulate the immune system is carried out. Bloodletting from specific blood vessels is also performed as a method of treatment. Further treatment methods include collyrium (Anjanam), fomentations, medicines applied to the whole body, inhalations (smoke or other medicaments) and fumigation. The prominence of certain veins and the hang of the tail help diagnosis and prognosis of certain diseases and conditions. Direct hand manipulation is a common method used to relive constipation and retained placenta. The aim of this study was to collect and preserve at least a portion of the traditional veterinary medical practices on cattle diseases in Sri Lanka.

\section{MATERIALS AND METHODS}

Treatment methods were gathered from traditional veterinary physicians in Central and Sabaragamuwa provinces who specialize in treating cattle diseases. Further data were collected from Sri Lankan traditional veterinary text books and olla leaves. Some 
selected formulae and treatments are presented in this paper.

\section{Oral and nasal administrations of medicines:}

\section{Oral administration of medicine to cattle}

A $60 \mathrm{~cm}$ long reed of Bambusa valgaris (Poaceae; Sinhala: Una) is used for this purpose. The inner surface of the reed is scraped carefully with the help of a knife and inner internodes are removed. Outer side is smoothened and one end is rounded. The rounded end of the reed is inserted into the animal's mouth up to the throat and medicines are poured in through other end of the reed.

\section{Nasal administration of medicine}

A $30 \mathrm{~cm}$ petiole of Carica papaya (Caricaceae; Sinhala: Gaslabu/ Pepol) is used for this purpose. One end of the petiole is inserted inside the cow's nostril and the medicine is poured to the cow's nostril from other end of the petiole.

\section{Preparation of Whey}

Sixty (60)g of curd is mixed with $250 \mathrm{ml}$ of water and beaten well for thirty minutes. The scum formed on the top of the mixture is removed and remainder is used as whey.

\section{RESULTS AND OBSERVATIONS}

According to this study it was observed that traditional veterinary physicians use different methods to treat cattle diseases such as charms, branding and medicinal preparations prepared with herbs and minerals. Some of the medicinal preparations used in treatment of cattle are given in table 1.

Some physicians use different charms to treat different diseases. They incant and recite various charms as a preventive measure during epidemics. They also use charms as a therapeutic measure to treat diseases such as worm infestations, dermatitis and hoof disease. A list of Charms is given in table 2.

Further, Sri Lankan traditional veterinary physicians practice branding to treat different cattle diseases. The diseases and points of branding are given in table 3.

These traditional veterinary physicians brand the tip of the tail for twenty types of 'Adappan' and, brand veins around the umbilicus for 'Sidannoi' diseases. Inhalations (Nasna) are used for Weppu (lethargy), Adassi (constipation), Adappan (nasal discharge and tremors), dyspepsia, and defecation with mucous and Sidannoi (passing faeces with mucous). Collyriums (Anjanam) are used for most diseases and specially for Weppu (lethargy) and constipa- tion. Method of Fumigation (Dum allima) is used for especially for 'Weppu' (lethargy). Fomentation is used for diseases of 'Weppu' (lethargy) and 'Adappan' (nasal discharge and tremors). Drugs are applied on whole body, especially for 'Weppu' (lethargy), shivering, fever, and 'Adassi' (constipation) diseases. Drugs are administered through the ear for diseases such as Weppu (lethargy), Adappan (nasal discharge and tremors), fever and defecation with mucous.

One of the special treatment methods for cattle is bloodletting treatment. When suffering from 'Adappan' the blood flow in the veins at the right side of the neck of the cow is hot to touch, vibrating like a bow-string and is very fast. Measure two inches from the joint of ulnar olecranon of the forefoot and puncture the vein downwards. If the blood flow is frothy and uniform colour, the animal is curable.

\section{DISCUSSION}

Traditional veterinary physicians use endemic plants such as L. zeylanica, C. albiflora, Z. officinale to treat cattle disease. One of the commonest has been the fresh plant of $P$. amboinicus. According to the study, traditional physicians treated mostly for gastrointestinal diseases, hoof diseases, infectious diseases and worm infestations. Various treatment methods and drug administering methods have been used in treating cattle. These physicians use different charms for different diseases, but some of these charms are common for treatment of most ailments as well as preventive measurers. Sri Lankan traditional veterinary physicians use different shapes of branding for various diseases and also as a preventive method. 
Table 1. Preparations used for different diseases and symptoms by Sri Lankan Veterinary Physicians

\begin{tabular}{lllll}
\hline \multicolumn{2}{c}{ Symptoms/ Disease } & \multicolumn{2}{c}{ prescription } \\
\hline Sinhala & \multicolumn{1}{c}{ English } & \multicolumn{1}{c}{ Botanical name\& amount } & Sinhala \\
\hline $\begin{array}{l}\text { Bade } \\
\text { Kakkuma }\end{array}$ & $\begin{array}{l}\text { Stomach- } \\
\text { ache }\end{array}$ & Alteranthera sessilis $200 \mathrm{~g}$ & Mukunu \\
& & & \\
& & & \\
Bade & Colicky & Cocos nucifer & $125 \mathrm{~g}$ & Pol \\
Gaya & Pain & Jasminum multiflorum & $125 \mathrm{~g}$ & Pichcha \\
& & Phylanthus embilica & $125 \mathrm{~g}$ & Nelli
\end{tabular}

\begin{tabular}{|c|c|c|c|}
\hline $\begin{array}{l}\text { Bada } \\
\text { Pipuma }\end{array}$ & Flatulence & $\begin{array}{l}\text { Aloe vera } \\
\text { Ferula asafoetide }\end{array}$ & $\begin{array}{l}100 \mathrm{~g} \\
5 \mathrm{~g}\end{array}$ \\
\hline
\end{tabular}

$\begin{array}{lllll}\begin{array}{l}\text { Kapu } \\ \text { kama } \\ \text { nodiravee } \\ \text { ma }\end{array} & \text { Dyspepsia } & \begin{array}{l}\text { Leucas zeylanica } \\ \text { Piper nigrum } \\ \text { Allium sativum } \\ \text { Vitex negundo }\end{array} & \begin{array}{l}15 \mathrm{~g} \\ 15 \mathrm{~g}\end{array} & \begin{array}{l}\text { Geta thumba } \\ \text { Gammiris } \\ \text { Sudu Loonu } \\ \text { Nika }\end{array} \\ \begin{array}{l}\text { Adassiya } \\ \text { and } \\ \text { Thatamee }\end{array} & \begin{array}{l}\text { Constipa- } \\ \text { tion }\end{array} & \begin{array}{l}\text { A. sativum } \\ \text { Acorus calamus } \\ \text { Crateva adansonii }\end{array} & 100 \mathrm{~g} & \text { Wadakaha } \\ \end{array}$

Mashuca longifolia

F.asafoetide

Sidannoi, Passing

Seedan

yanawata

aeces

mixed with

Mucous
A.sativum

A.vera

Leucas zeylanica

$50 \mathrm{~g}$

$50 \mathrm{~g}$

$50 \mathrm{~g}$

Geta Thumba

Acalypha indica Atalantia ceylanica Zingiber officinale Acasia caesia

Citrus aurantifolia

$5 \mathrm{~g}$
$5 \mathrm{~g}$
$5 \mathrm{~g}$

Kuppameniya Yakinaran

Inguru

Hinguru pata

$30 \mathrm{ml}$

$\begin{array}{lll}\text { Annona cherimolar } & 150 \mathrm{~g} & \text { Anoda } \\ \text { Tephrosia purpurea } & 150 \mathrm{~g} & \text { Katupila } \\ \text { Ipomea obscura } & 150 \mathrm{~g} & \text { Thal } \\ \begin{array}{l}\text { Sida cordifolia } \\ \text { Physalis micrantha }\end{array} & 150 \mathrm{~g} & \text { Babila } \\ \begin{array}{l}\text { Abelmoschus mos- } \\ \text { chantus }\end{array} & 150 \mathrm{~g} & \begin{array}{l}\text { Mottu } \\ \text { Kapukinissa }\end{array} \\ \begin{array}{l}\text { Triumfetta rhom- } \\ \text { boided }\end{array} & 150 \mathrm{~g} & \text { Apala } \\ \text { Chrysopogon acicula- } & 150 \mathrm{~g} & \\ \text { Tur } & 150 \mathrm{~g} & \text { Thuththiri }\end{array}$
Anoda) and Tephrosia purpurea (Fabaceae; Sinhala: Katupila),Leaves of Ipomea obscura (convolvulaceae; Sinhala: Thal), Sida cordifolia (Malvaceae; Sinhala: Babila), Physalis micrantha (Solanaceae; Sinhala: Mottu) \& Abelmoschus moschantus (Malvaceae; Sinhala: Kapukinissa) roots of Triumfetta rhomboided (Family: Liliacea; Sinhala name: Apala) and Chrysopogon aciculatus (Poaceae; Sinhala: Thuththiri ) are pounded together. $240 \mathrm{ml}$ of Coconut milk is added to the mixture. The mixture is boiled in an earthen pot. This mixture is given orally twice a day. Dosage: $450 \mathrm{ml}$, twice a day. on to coconut-shell charcoal embers. The rising smoke is directed to fumigate the anal region of the cow. Heartwood of Mashuca longifolia (Sapotaceae; Sinhala: Mee) is junctiva of both eyes.

$50 \mathrm{~g}$ each of $F$.asafoetide and of $A$.sativum latex are ground well with fresh juice of $A$.vera. Fresh juice of $A$.vera is added in to the above thick juice till the final volume is $375 \mathrm{ml}$. Dosage: ing day, orally.

150 of fresh leaves of Leucas zeylanica (Lamiaceae; Sinhala: added till the final volume is $375 \mathrm{ml}$. Dose $375 \mathrm{ml}$ orally twice a day.

$5 \mathrm{~g}$ each of Acalypha indica (Euphobeacea; Sinhala: Kuppameniya), Atalantia ceylanica (Rutaceae; Sinhala: Yakinaran) tender
leaves, rhizome of Zingiber officinale (Zingiberacea; Sinhala: Inguru) and common salt are ground with juice of Acasia caesia (Fabacea; Sinhala: Hinguru pata) to a paste. $30 \mathrm{ml}$ of juice of Citrus aurantifolia (Rutacea; Sinhala: Dehi) is mixed with above
paste. $15 \mathrm{ml}$ of mixture is poured into each nostril of the cow.

tus

Thuththiri 


\begin{tabular}{|c|c|c|c|c|}
\hline Anuppili & $\begin{array}{l}\text { Constipation } \\
\text { \& Abdominal } \\
\text { Distention }\end{array}$ & Ficus racemes & $200 \mathrm{~g}$ & Attikka \\
\hline Ugurata ema & Regurgitation & $\begin{array}{l}\text { Plectranthus am- } \\
\text { boinicus }\end{array}$ & $200 \mathrm{~g}$ & $\begin{array}{l}\text { Kappa- } \\
\text { rawalliya }\end{array}$ \\
\hline $\begin{array}{l}\text { AyulkaiA- } \\
\text { yulkai }\end{array}$ & $\begin{array}{l}\text { Excessive } \\
\text { Salivation }\end{array}$ & $\begin{array}{l}\text { F. racemosa } \\
\text { Melia azedarach } \\
\text { Ziziphus lucida }\end{array}$ & $\begin{array}{l}150 \mathrm{~g} \\
150 \mathrm{~g}\end{array}$ & $\begin{array}{l}\text { Midella } \\
\text { Eraminiya }\end{array}$ \\
\hline $\begin{array}{l}\text { Gini adap- } \\
\text { pan }\end{array}$ & Melina & $\begin{array}{l}\text { Terminalia bellirica } \\
\text { Cannabis sativa } \\
\text { Trachyspermum } \\
\text { roxburghianum } \\
\text { Dioscorea pen- } \\
\text { taphylla } \\
\text { D.pentaphylla }\end{array}$ & $\begin{array}{l}100 \mathrm{~g} \\
50 \mathrm{~g} \\
50 \mathrm{~g}\end{array}$ & $\begin{array}{l}\text { Bulu } \\
\text { Ganja } \\
\text { Asamodagam } \\
\text { Katuwala }\end{array}$ \\
\hline
\end{tabular}

$200 \mathrm{~g}$ of leaves and bark of Ficus racemes (Moraceae; Sinhala: Attikka) are cut in to small pieces and pounded well. It is then steamed and squeezed well. Juice is extracted by adding water till the final volume is $375 \mathrm{ml}$. $25 \mathrm{ml}$ of coconut vinegar is added in to the above juice. $400 \mathrm{ml}$ above juice is given orally twice a day.

$200 \mathrm{~g}$ of fresh entire plant of Plectranthus amboinicus (Lamiaceae; Sinhala: Kapparawalliya) are cut into small pieces and pounded together and juice is extracted by adding water till the final volume is $375 \mathrm{ml}$. $25 \mathrm{ml}$ of sesame oil is added in to the above fresh juice. Dosage: $400 \mathrm{ml}$ twice a day, orally.

$150 \mathrm{~g}$ each of bark of $F$ racemosa and Melia azedarach (Maliaceae; Sinhala: Midella) and chimney-soot are ground well. Prick the tongue of the animal with a thorn of Ziziphus lucida (Rhamnaceae; Sinhala: Eraminiya) and allow to bleed few drops. Then apply the medicine on the tongue.

$100 \mathrm{~g}$ of pericarp of Terminalia bellirica (Combretaceae; Sinhala: Bulu) and 50g each of leaves Cannabis sativa (Moraceae; Sinhala: Ganja) and Trachyspermum roxburghianum (Apiaceae; Sinhala: Asamodagam) are cut into small pieces and ground together with juice of roots of $\mathrm{Di}$ oscorea pentaphylla (Dioscoreaceae; Sinhala: Katuwala) till it turns in to a fine paste. Roots of $D$.pentaphylla are pounded and juice extracted by squeezing and is added to the above paste till the final volume is $375 \mathrm{ml}$. The mixture is boiled in an earthen pot Dosage: $375 \mathrm{ml}$, twice a day, orally.

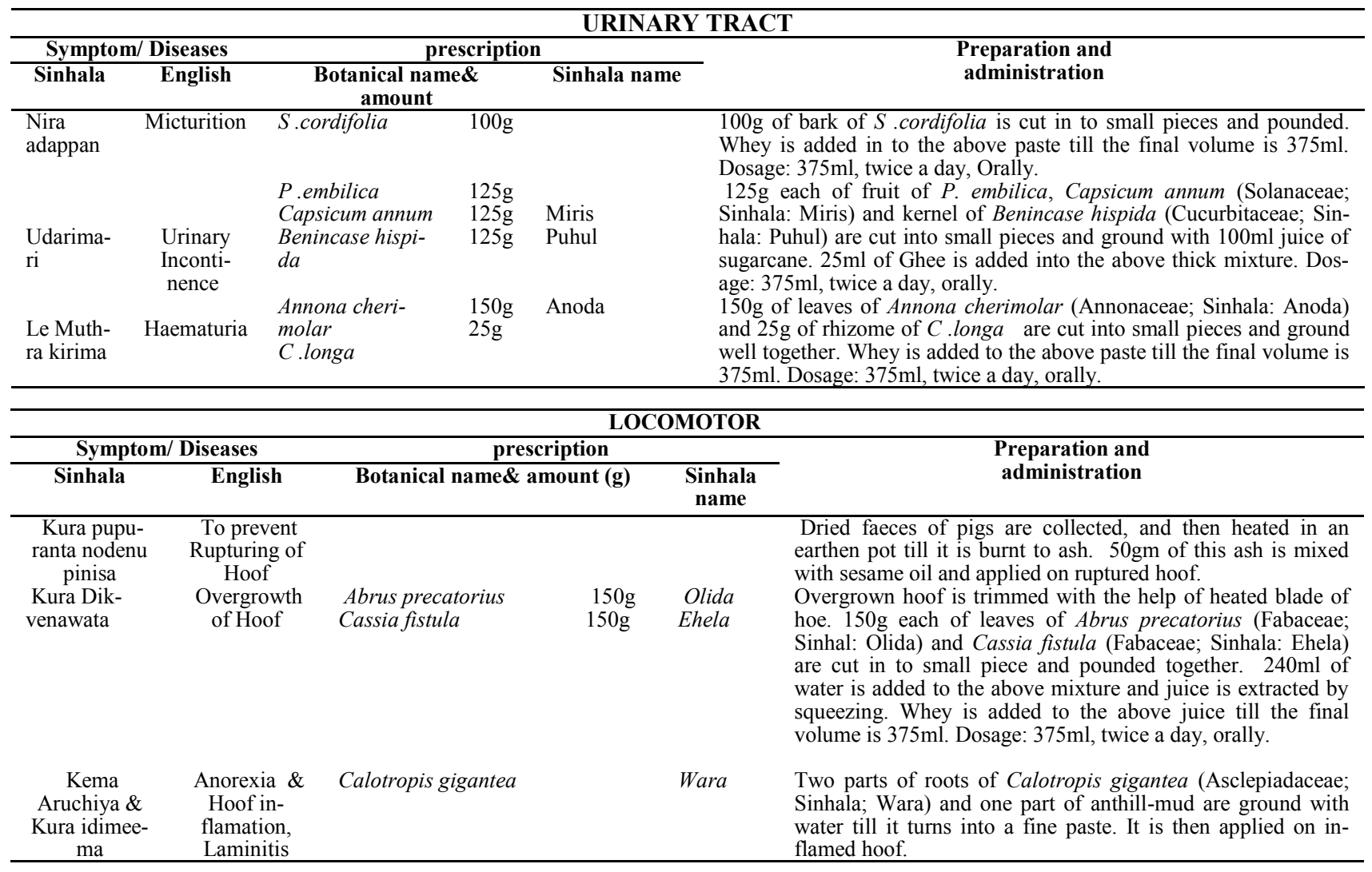




\begin{tabular}{|c|c|c|c|c|}
\hline \multicolumn{5}{|c|}{ SKELITO MUSCULAR } \\
\hline \multicolumn{2}{|c|}{ Symptom/Diseases } & \multicolumn{2}{|c|}{ prescription } & \multirow{2}{*}{$\begin{array}{l}\text { Preparation and } \\
\text { administration }\end{array}$} \\
\hline Sinhala & English & $\begin{array}{l}\text { Botanical name\& } \\
\text { amount (g) }\end{array}$ & $\begin{array}{c}\text { Sinhala } \\
\text { name }\end{array}$ & \\
\hline $\begin{array}{l}\text { Harakage } \\
\text { Wane } \\
\text { panuwan } \\
\text { eliyata } \\
\text { ema }\end{array}$ & $\begin{array}{l}\text { To remove } \\
\text { maggots in } \\
\text { the wounds }\end{array}$ & $\begin{array}{l}\text { Erythrina } \\
\text { variegate } \\
\text { Nicotina taba- } \\
\text { cum } \\
\text { Typhonium } \\
\text { trialobatum } \\
\text { Solanum xan- } \\
\text { thocarpem }\end{array}$ & $\begin{array}{l}\text { Erabadu } \\
\text { Dumkola } \\
\text { Panu ala } \\
\text { Batu }\end{array}$ & $\begin{array}{l}\text { Two parts each of leaves of Erythrina variegate (Fabaceae; Sinhala: Erabadu), } \\
\text { Nicotina tabacum (Solanaceae; Sinhala: Dumkola), rhyzome of Typhonium } \\
\text { trialobatum (Araceae; Sinhala: Panu ala), fruit of Solanum xanthocarpem } \\
\text { (Solanaceae; Sinhala: Batu) are cut into small pieces Two part of chimney-soot } \\
\text { and one part of lime are added into the above mixture. The mixture is ground } \\
\text { together till it turns to a fine paste. This past is kept over the wounds to cover } \\
\text { the whole cavity. This paste helps to extrude maggots and promote healing. }\end{array}$ \\
\hline \multirow[t]{2}{*}{$\begin{array}{c}\text { Wane } \\
\text { suwa } \\
\text { weemata }\end{array}$} & $\begin{array}{l}\text { To enhance } \\
\text { the Healing } \\
\text { of Wounds }\end{array}$ & $\begin{array}{l}\text { Strychnos nux } \\
\text { - vomic }\end{array}$ & Godakaduru & $\begin{array}{l}\text { Two parts of bark of Strychnos nux - vomic (Loganiacea; Sinhala: Godakaduru) } \\
\text { are pounded with one part of brick powder. This paste is applied to cover the } \\
\text { wound. }\end{array}$ \\
\hline & & $\begin{array}{l}\text { Morinda citri- } \\
\text { folia } \\
\text { C. Longa }\end{array}$ & Ahu & $\begin{array}{l}\text { Two parts of tender leaves of Morinda citrifolia (Rubiaceae; Sinhala: Ahu) and } \\
\text { one part of rhizome of C. Longa are pounded together. Above paste is mixed } \\
\text { with sesame oil and heated in an earthen pot till it cooked. This preparation is } \\
\text { laced on the wound. }\end{array}$ \\
\hline
\end{tabular}

\begin{tabular}{|c|c|c|c|c|c|}
\hline \multicolumn{6}{|c|}{ OTHER SYSTEMS } \\
\hline \multicolumn{2}{|c|}{ Symptom/ Diseases } & \multicolumn{3}{|c|}{ prescription } & \multirow{2}{*}{$\begin{array}{l}\text { Preparation and } \\
\text { administration }\end{array}$} \\
\hline Sinhala & English & Botanical name & t (g) & Sinhala name & \\
\hline \multirow[t]{2}{*}{$\begin{array}{l}\text { Weppu } \\
\text { Diseases }\end{array}$} & Lethargy & P.amponicus & $200 \mathrm{~g}$ & & $\begin{array}{l}200 \mathrm{~g} \text { of fresh entire plant of } P \text {.amponicus are cut in to small } \\
\text { pieces and pounded. Juice is extracted by adding water till } \\
\text { the final volume is } 375 \mathrm{ml} .25 \mathrm{ml} \text { of sesame oil is added into } \\
\text { the above juice and stirred well. } 400 \mathrm{ml} \text { of above juice is } \\
\text { given orally twice a day. }\end{array}$ \\
\hline & & $\begin{array}{l}\text { Spondias pinnata } \\
\text { Cinnamomum } \\
\text { zeylanicym }\end{array}$ & $\begin{array}{l}100 \mathrm{~g} \\
100 \mathrm{~g}\end{array}$ & $\begin{array}{l}\text { Wal Ambarella } \\
\text { Kurundu }\end{array}$ & $\begin{array}{l}100 \mathrm{~g} \text { each of leaves of Spondias pinnata (Anacardiaceae; } \\
\text { Sinhala: Wal Ambarella) and Cinnamomum zeylanicym } \\
\text { (Lauraceae; Sinhala: Kurundu) are pounded together. Juice is } \\
\text { extracted by adding water till the final volume is } 375 \mathrm{ml} \text {. four } \\
\text { eggs are mixed with above juice and stirred well. Above } \\
\text { fresh juice is given orally twice a day. }\end{array}$ \\
\hline
\end{tabular}

$\begin{array}{lrl}\text { Alpinia nigra } & 15 \mathrm{~g} & \text { Kelaniya } \\ \text { A. sessilis } & 15 \mathrm{~g}\end{array}$

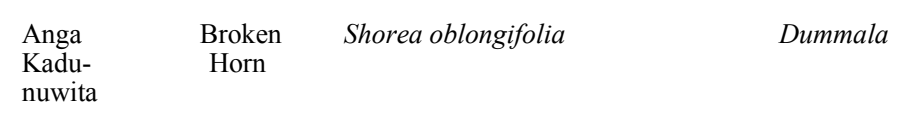

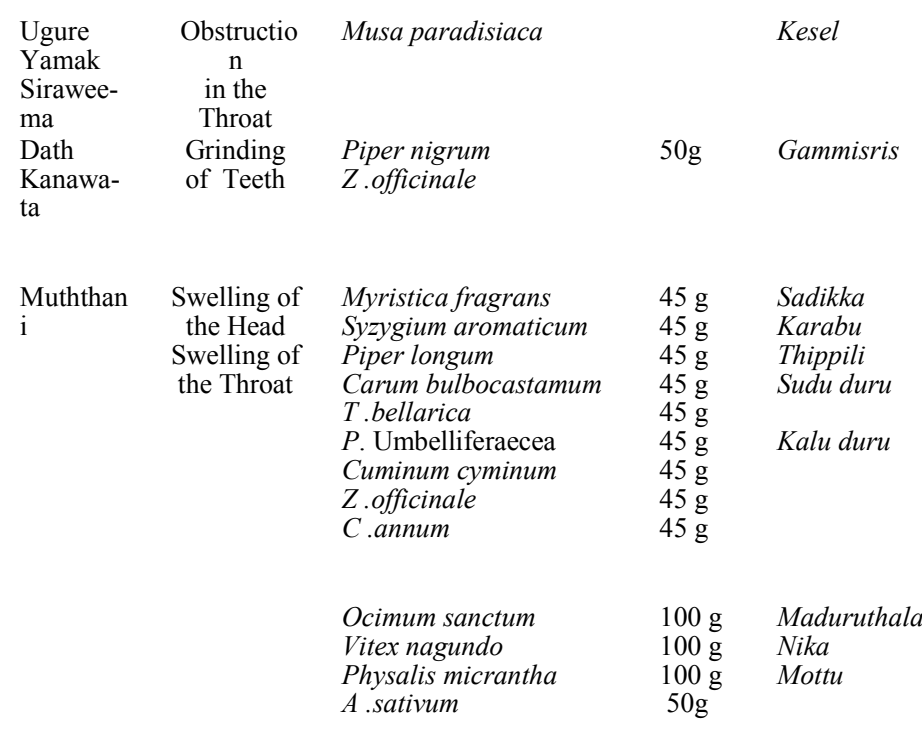

$15 \mathrm{~g}$ each of leaves of Alpinia nigra (Zingiberacea; Sinhala: Kelaniya), A. sessilis, orange juice are ground together. $30 \mathrm{ml}$ of water is added to the above mixture and juice is extracted by squeezing. Then $15 \mathrm{ml}$ of this juice is poured in to each ear of the cow.

Resin of Shorea oblongifolia (Dipterocarpacea; Sinhal: Dummala) is mixed with coconut oil. The mixture is put into an earthen pot, heated till burnt to ashes. Ash is kept over broken horn and tied with human hair.

Two parts of spider web mixed with one part of lime. This paste is also applied over the broken place.

A pith of Musa paradisiaca (Musaceae; Sinhala: Kesel) with the size of $15 \mathrm{~cm}$ width and $30 \mathrm{~cm}$ length is carefully inserted through the esophagus to remove the obstruction.

$50 \mathrm{~g}$ of seeds of Piper nigrum (Piperaceae; Sinhala: Gammisris) is ground well with juice of $Z$.officinale till it turns to fine paste. Then juice of $Z$.officinale is added to above paste till the final volume is $375 \mathrm{ml}$. Dosage: $375 \mathrm{ml}$, twice a day, Orally.

$45 \mathrm{~g}$ each of fruit of Myristica fragrans (Family: Myristicaeat; Sinhala name: Sadikka) clove of Syzygium aromaticum (Family; Myrtaceae; Sinhala name: Karabu), seeds of Piper longum (Family: Pipreraceae; Sinhala name: Thippili), Carum bulbocastamum (Family: Umbelliferaecea; Sinhala name: Sudu duru), pericarp of $T$.bellarica, $P$. Umbelliferaecea; Sinhala name: Kalu duru), Cuminum cyminum (Family: Umbelliferaecea), rizome of $Z$.officinale and fruit of $C$. annum are pounded together till it turns to a fine paste. $25 \mathrm{ml}$ of ghee is added to above paste and the above mixture is given orally twice a day. $100 \mathrm{~g}$ each of leaves of Ocimum sanctum (Lamiaceae; Sin-
hala: Maduruthala), Vitex nagundo (Verbenaceae; Sinhala A.sativum $\quad 50 \mathrm{~g}$ Nika) and Physalis micrantha (Solanaceae; Sinhala: Mottu) are pounded together. Juice is extracted by squeezing and water is added till the final volume is $300 \mathrm{ml}$. $50 \mathrm{~g}$ of carpel of A sativum is ground well and added into above juice. $25 \mathrm{ml}$ vinegar is stirred well to the above fresh juice. Dosage: $375 \mathrm{ml}$, twice a day, Orally. 
Wewlee-

ma

Shivering

Brassica juncea
$P$.nigrum
Acasia caesia

A. nigra

C. albiflora

$Z$.officinale

$M$. oleifare

Crotalaria la-

burnifolia

Albizia amara

P. amboinicus

Kara

thalmata

Bruising of Lisea glutinosa
neck \&

Contusion

Citrus hystrix

$100 \mathrm{~g}$

Kudalu

dehi

100g Diya

Labu

Ankenda Malla

E. variegate

Acronychia
pedunculata

Olac zeylanica

C. nucifera

C. longa

Wassange Worm T. roxburghia-

Panu

Ledata

Infestation

in Calves

Centrella asiati-

ca

Allium cepa

Azadirachta

indica

A .cepa

Sama

Roga-

For Any

Disease

Cymbopogon

nardus

V.negando

C. procera

Pogostemon

negnenus

Sinakkaram

$\begin{array}{ll}\text { Sinakkaram } & 10 \mathrm{~g} \\ \text { Copper Sulphate } & 10 \mathrm{~g}\end{array}$

Croton tigeium $10 \mathrm{~g}$

L .zeylanica
$10 \mathrm{~g}$ each of seed of Brassica juncea (Brassicaceae; Sinhala: Aba) and P .nigrum are ground and mixed with $30 \mathrm{ml}$ of juice of Acasia caesia (Family ;Fabaceae: Sinhala name:Higurapata). $15 \mathrm{ml}$ of this mixture is poured in to each nostril of the gurapata cow.

Yakberiya $200 \mathrm{~g}$ each of rhizome of A. nigra, C. albiflora and $Z$.officinale, root of $M$. oleifare, Leaves of Crotalaria laburnifolia (Fabacea; Sinhala: Yakberiya), Albizia amara (Fabacea; Sinhala: Iha ) and P. amboinicus are pounded together. $1500 \mathrm{ml}$ of water is added to the above mixture and juice is extracted by squeezing. The extract is then boiled in an earthen pot.This is applied over the whole body.

Apply human urine on the contusion without speaking

Bark of Lisea glutinosa (Lauraceae; Sinhala: Bombue) is scraped and ground with common salt water. This paste is applied on the contusion.

$100 \mathrm{~g}$ of fruit of Citrus hystrix (Rutaceae; Sinhala: Kudalu dehi) is mixed with $240 \mathrm{ml}$ of water and cooked in an earthen pot. These fruits are then ground well with sesame oil. This paste is applied on contusion.

$100 \mathrm{~g}$ of kernal of Lagenaria sicerearia (CucurbiItaceae; Sinhala: Diya Labu) are boiled with $60 \mathrm{ml}$ of coconut milk. This paste is applied to loosen the stiffened areas.

Two parts of each of leaves and bark of E. variegate, Acronychia pedunculata (Rutaceae; Sinhala: Ankenda), Olac zeylanica (Olaceaceae, Sinhala: Malla) and one part tender leaves of $C$. nucifera, rhizome of $C$. longa and scraped coconut are pounded together. Juice is extracted by adding water and then heated on an earthen pot till it boils. Above mixture is applied on hardened contusion.

$50 \mathrm{~g}$ of each of entire plant of T. roxburghianum, Centrella asiatica (Apiaceae; Gotu kola Sinhala: Gotu kola) and carpal of Allium cepa (Family: Alliaceae; Sinhala name: Rathulunu Rathulunu) are boiled together and this is given orally twice a day.

$100 \mathrm{~g}$ Kohomba $100 \mathrm{~g}$ of bark of Azadirachta indica (Meliaceae; Sinhala: Kohomba) and carpal of A .cepa are cut in to small pieces. $750 \mathrm{ml}$ of water is added to the above mixture is boiled in an earthen pot till it is reduced to $375 \mathrm{ml}$. Dosage: $375 \mathrm{ml}$, twice a day, Orally.

$100 \mathrm{~g}$ of each of roots of Cymbopogon nardus (Poaceae: Sinhala: Pagirimana), V.negando and leaves of C. procera, Pogostemon negnenus (Lamiaceae; Sinhala: Kollnkola) are cut in to small pieces and pounded together. $375 \mathrm{ml}$ of Juice is extracted by adding water and squeezing. Above juice is heated on leathern pot Kollnkola till it boiled. Dosage: $375 \mathrm{ml}$, twice a day, Orally.

$10 \mathrm{~g}$ each of powder of Sinakkaram, Copper Sulphate, seeds of Croton tigeium (Euphobeacea; Sinhala: Jayapala) are ground with juice of L .zeylanica to a fine paste and is allowed to partially dry in wither. Then small pills are prepared and dried well. These pills are dissolved in water and applied on in to the lower palpable conjunctiva of cow's eyes. 
Table 2: Charms for Different Diseases

\begin{tabular}{|c|c|}
\hline INDICATION & CHARMS \\
\hline $\begin{array}{l}\text { To enhance healing } \\
\text { of the wounds }\end{array}$ & $\begin{array}{l}\text { Take } 5 \mathrm{~g} \text { of ash from hearth. Enchant the ash by reciting seven times, the charm (Mantra) given below. 'Om namo } \\
\text { shrimabokanda pesi giya agnawen anubawen asawalage asawal gawayage asawal peththe wane sidhi sidhi sidhi } \\
\text { eswahah'. } \\
\text { Take } 5 \mathrm{~g} \text { of mustard seeds. Enchant it by reciting seven times, the charm (Mantra) given below and put in to the } \\
\text { hearth. 'Om namo sabarek dara palai sabarek dara genei sabarek gini genei sabarek gini karai. noda puthek inda } \\
\text { mathurai.asawalage asawal gawayage asawal peththe wane panuwo selethwa selethwa selethwa' }\end{array}$ \\
\hline Lethargy (Weppu) & $\begin{array}{l}\text { Recite following charms (Mantra). 'Om shri vishnu narayane girahakas obben piri pisadiyen wela ganda min yan } \\
\text { yen anda weppun manda weppun pisada weppun jawara weppun kama weppun manda weppun kattarun kotta } \\
\text { mala weppun achcharin arinus podi weppun pattumangara swamiyane po'. } \\
\text { Recite following charms (Mantra). 'Om ishwara vishnu thrikrasman wewai divya muka shri kru vishnu araksha } \\
\text { santhu jiwaka maheswara arakshanthu dewathi thejaggan bodhimara hitawa rakshan mohu isa sita kanda sathar- } \\
\text { gathe sarwa arakshanthu'. }\end{array}$ \\
\hline & $\begin{array}{l}\text { Recite following charms (Mantra) 'Om muni wesamuni anayen visadi durukota araksha balakota sathvitak siddha } \\
\text { sima bendeswah'. }\end{array}$ \\
\hline For Any disease & $\begin{array}{l}\text { Recite following charms (Mantra). 'Om namo shrimuni namo gringamuni namo sri wajra muni namo om akasha } \\
\text { om patala kapala sunkri om ravi grihagan namo wata pelenden sak mudu deke wata sitinne dahasak budunne se- } \\
\text { wane mage kesagraya patan nabagraya dakwa siyalu apranthu grahabenden sath patak sathdharana yak siddha } \\
\text { sima benden mema watakota araksha om kre e ra nathan enthala indiran enthanwala thallin kippada irimal ennok } \\
\text { malawel elendes erimarichchi eththap pachtubahu visadipogu poga yeswahah'. }\end{array}$ \\
\hline $\begin{array}{l}\text { To protect calves } \\
\text { from Leopards }\end{array}$ & $\begin{array}{l}\text { Take } 240 \mathrm{ml} \text { of milk. Enchant it by reciting the given charm (Mantra) } 108 \text { times. 'Om grin budu sarani, dham sara- } \\
\text { ni, sanga sarani prndum sohani eswahah'. }\end{array}$ \\
\hline $\begin{array}{l}\text { To cure cows of } \\
\text { non-lactation./ } \\
\text { To Improves cow's } \\
\quad \text { lactation }\end{array}$ & $\begin{array}{l}480 \mathrm{ml} \text { of water to be enchanted by reciting the given charm (Mantra) 'Namo Chandra gamanaya kiri muhude kiri } \\
\text { palu gase wata inne kiri sakkumara dewatha maheswarayanange yddedi dhasak denunge kiri pudu nermitha kara- } \\
\text { wa kiri dewu anubawayen vijamba kamala nimala sakala dhathu upula upula burulle kshira dhara shiddi sidhi } \\
\text { matharaksharayah'. }\end{array}$ \\
\hline For protection of & $\begin{array}{l}\text { Enchant water with the following charm (Mantra) and sprinkle water around on the cattle. 'Om ayruthn thris } \\
\text { narupan dukkha roga vinashayathi rathanathri warsanam suba wardhan namo namk'. }\end{array}$ \\
\hline
\end{tabular}

Table 3: Places of Branding for Diseases

\begin{tabular}{|c|c|c|c|c|}
\hline \multicolumn{2}{|c|}{ DISEASE / SYMPTOM } & \multicolumn{2}{|c|}{ PLACE OF BRANDING } & \multirow[b]{2}{*}{ SHAPE OF BRANDING } \\
\hline English Name & Sinhala Name & English Name & Sinhala Name & \\
\hline Colicky pain & Bade Gaya & Under the scapular region & Ila pita & \\
\hline Laminitis & Aruchi + Kura idimuma & Under the scapular region & Ila pita & \\
\hline Emaciation & $\begin{array}{l}\text { Haraka Dira kettuwee- } \\
\text { ma }\end{array}$ & $\begin{array}{l}\text { Both side of divergent } \\
\text { hair vertex at withers }\end{array}$ & Molliya depasa & \\
\hline Constipation & Adassiya & $\begin{array}{l}\text { Around ventral } \\
\text { neck area }\end{array}$ & Karawata & \\
\hline $\begin{array}{l}\text { Nasal discharge } \\
\text { and tremors }\end{array}$ & All adappan & $\begin{array}{l}\text { Both side lateral to the } \\
\text { thoracic vertebral columns }\end{array}$ & Depita & \\
\hline Stomachache & Bade Kakkuma & $\begin{array}{l}\text { When the cow is in stand- } \\
\text { ing } \\
\text { posture, a posterior } \\
\text { surface of lumbar coccyg- } \\
\text { eal groove }\end{array}$ & Hellawala & \\
\hline Dried tongue & Diwa Weleema & $\begin{array}{c}\text { When the cow is in stand- } \\
\text { ing } \\
\text { posture, a posterior } \\
\text { surface of Lumbar coccyg- } \\
\text { eal groove }\end{array}$ & Hellawala & \\
\hline Flatulence & Bada Pipuma & $\begin{array}{c}\text { In between the vertebral } \\
\text { column and tuber coccyge- } \\
\text { al area }\end{array}$ & Ala pita & \\
\hline
\end{tabular}


Constipation \& abdominal distention

Lethargy

Defecation with mucous

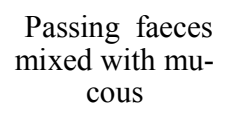

\section{Shivering}

Swelling of head and neck

\section{Hoof diseases}

Haematuria

Regurgitation

Grinding of teeth

Dath kama

Area of the ulana Olecranon

Excess Salivation

When the cow is in standing posture, a posterior surface of right side of the lumbar coccygeal groove

When the cow is in standing posture, a posterior surface of left side of the lumbar coccygeal groove

In between the lumbar and coccygeal area

In between the vertebral column and tuber coccygeal area

When the cow is in standing posture, a posterior surface of right side of the Lumbar coccygeal

Area of the position of fetlock joint

Dorsal surface around the neck area

When the cow is in standing posture, a posterior surface of Lumbar coccygeal groove

Both side lateral to the thoracic vertebral columns

Around the

Navel area

Ugurata Ema

Area between thoracic and Umbilicus
Dakunu Hellawala

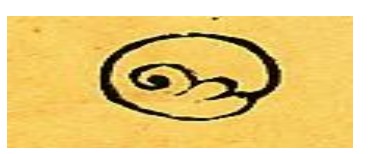

Wam Hallawala

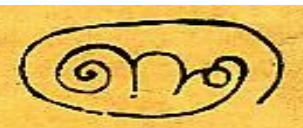

Dela

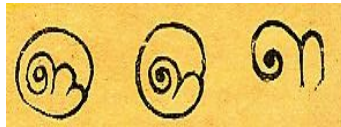

Alapita

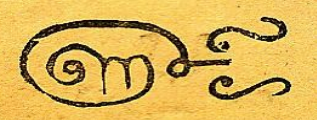

Dakunu Hellawala

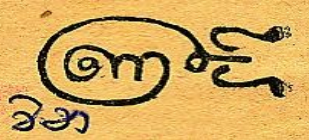

Ath deke pathu pita

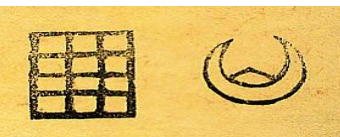

Bella

Hellawala

Depita

Bada dela
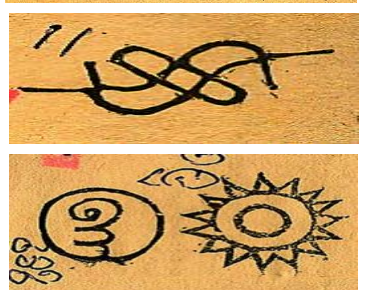

Atha Poruwa

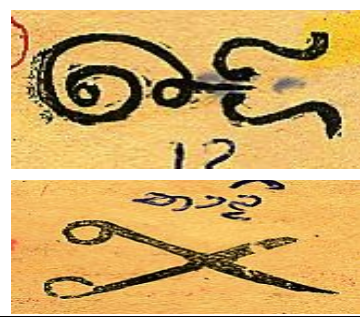

Bada meda
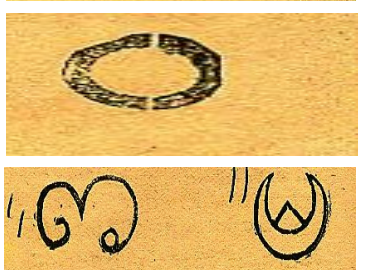

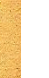

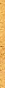

Prera GS 1968 Gawa Wedakama, Modern book Ltd, Nugegoda, Sri Lanka.

Anonymous 1963 Rathna Book Shop, Colombo, Sri Lanka.

Bandaranayaka WM and Sultanbawa MUS 1991 Forest Information Service, Forest Department, Rajamallwate Road, Battaramulla, Colombo, Sri Lanka.

\section{REFERENCES}

Senaratna LK 2001 A check list of the Flowering plants of Sri Lanka, National Science Foundation, Colombo, Sri Lanka. 